\title{
Novosphingobium pentaromativorans sp. nov., a high-molecular-mass polycyclic aromatic hydrocarbon-degrading bacterium isolated from estuarine sediment
}

\author{
Jae Hak Sohn, † Kae Kyoung Kwon, Ji-Hyun Kang, Hong-Bae Jung \\ and Sang-Jin Kim \\ Microbiology Laboratory, Korea Ocean Research \& Development Institute, Ansan, PO Box 29, \\ 425-600, Republic of Korea
}

Correspondence

Sang-Jin Kim

s-jkim@kordi.re.kr

\begin{abstract}
A Gram-negative, yellow-pigmented, halophilic bacterial strain US6-1 ${ }^{\top}$, which degrades high-molecular-mass polycyclic aromatic hydrocarbons of two to five rings, was isolated from muddy sediment of Ulsan Bay, Republic of Korea. The 16S rRNA gene of the isolate showed high sequence similarity to Novosphingobium subarcticum (96.23\%) and Sphingopyxis alaskensis (96.18\%); however, the isolate formed a distinct phyletic line within the genus Novosphingobium. DNA-DNA relatedness between US6-1 ${ }^{\top}$ and the closest strain $N$. subarcticum revealed that strain US6-1 ${ }^{\top}$ was independent from this species. Isolate US6-1 ${ }^{\top}$ had ubiquinone 10 and a DNA $\mathrm{G}+\mathrm{C}$ ratio of $61 \cdot 1 \mathrm{~mol} \%$. Major fatty acids were octadecanoic acid $(18: 1 \omega 7)$, hexadecanoic acid $(16: 1 \omega 7)$ and 2-hydroxy-myristic acid $(14: 02-\mathrm{OH})$. On the basis of polyphasic taxonomic evidence, strain US6-1 ${ }^{\top}$ is proposed to represent a novel species in the genus Novosphingobium for which the name Novosphingobium pentaromativorans sp. nov. is proposed. The type strain is US6-1 ${ }^{\top}\left(=\operatorname{KCTC} 10454^{\top}=\mathrm{JCM} 12182^{\top}\right)$.
\end{abstract}

Polycyclic aromatic hydrocarbons (PAHs) are ubiquitous environmental pollutants. They have accumulated in the environment as a result of various anthropogenic activities. Elevated PAH concentrations are found in the sediments of coastal embayments, estuaries and the continental shelf, where human pressure is felt most noticeably (Sanger et al., 1999). Contamination of marine sediments by PAHs is of concern because some of these hydrocarbons have toxic, carcinogenic and genotoxic properties. Therefore, removal of PAHs from contaminated environments is of considerable concern. Many micro-organisms have important roles in transformation and degradation of PAHs in the environment and micro-organisms that are able to degrade PAHs have been isolated from various environments (Shin et al., 1999; Juhasz \& Naidu, 2000).

We isolated a moderately halophilic, yellow-pigmented

\footnotetext{
Published online ahead of print on 20 February 2004 as DOI 10.1099/ ijs.0.02945-0.

tPresent address: Department of Marine Biotechnology, Silla University, Busan 617-736, Republic of Korea.

Abbreviations: $\beta$-HPCD, 2-hydroxypropyl $\beta$-cyclodextrin; PAHs, polycyclic aromatic hydrocarbons.

The GenBank/EMBL/DDBJ accession number for the 16S rRNA gene sequence of strain US6- $1^{\top}$ is AF502400.
}

bacterial strain US6- $1^{\mathrm{T}}$ from estuarine sediment at Ulsan Bay, Republic of Korea. This bacterium can degrade PAHs of between two and five rings. Taxonomic characteristics of strain US6- $1^{\mathrm{T}}$ are reported.

About $1 \mathrm{~g}$ sediment was inoculated into $10 \mathrm{ml}$ MM2 broth containing $\left[1^{-1}\right.$ aged sea water (ZoBell, 1946), pH 7.2]: $18 \mathrm{mM} \quad\left(\mathrm{NH}_{4}\right)_{2} \mathrm{SO}_{4}, 1 \mu \mathrm{M} \quad \mathrm{FeSO}_{4} .7 \mathrm{H}_{2} \mathrm{O}$ and $100 \mu \mathrm{l} 1 \mathrm{M} \mathrm{KH} \mathrm{KO}_{4} / \mathrm{Na}_{2} \mathrm{HPO}_{4}$ buffer solution, supplemented with 1000 p.p.m. of a final mixture of PAHs consisting of equal quantities of naphthalene, fluorene, phenanthrene, anthracene, fluoranthene and pyrene. After 2 weeks incubation at $25^{\circ} \mathrm{C}, 1 \mathrm{ml}$ culture broth was transferred to $10 \mathrm{ml}$ fresh medium. Sequential transfers were performed every 2 weeks on three occasions each. $\mathrm{PAH}$-degrading bacteria were isolated according to the spray-plating method of Kiyohara et al. (1982). One of the colonies formed a clear zone in the pyrene-sprayed MM2 agar plate after 20 days incubation at $25^{\circ} \mathrm{C}$. This strain $\left(\right.$ US6- $1^{\mathrm{T}}$ ) was subcultivated on marine agar 2216e (MA; Difco) or trypticase soy agar (TSA; Difco) for morphological and biochemical characterization.

Bacterial cells precultured in marine broth 2216e (MB; Difco) for 1 day at $25^{\circ} \mathrm{C}$ were harvested by centrifugation $(8000 \mathrm{~g}$, $10 \mathrm{~min}$ ) and inoculated into MM2 broth containing PAH mixtures (10 p.p.m. each of pyrene, benz[a]anthracene, 
chrysene, benz[b]fluoranthene and benzo[a]pyrene; Aldrich) and $10 \%(\mathrm{w} / \mathrm{v}) 2$-hydroxypropyl $\beta$-cyclodextrin $(\beta$-HPCD). After 8 days incubation, PAHs from culture broth were extracted with $n$-hexane and quantitative analysis was performed using GC/MS (Varian Saturn 2000). After 8 days incubation strain US6- $1^{\mathrm{T}}$ had degraded $88 \cdot 2-99 \cdot 9 \%$ of the supplemented PAHs (Fig. 1).

Air-dried smears from MA cultures were stained using the Bio-Rad Gram-staining kit according to the manufacturer's instructions to determine the Gram reaction. Motility was determined with an optical microscope (Zeiss Axioplan) using the hanging drop technique (Skerman, 1967). For scanning electron microscopy (SEM), strain US6- $1^{\mathrm{T}}$ was fixed with $4 \%$ glutaraldehyde. After washing with $50 \mathrm{mM}$ HEPES buffer $(\mathrm{pH} 7 \cdot 5)$ and post-fixation with $2 \% \mathrm{OsO}_{4}$ solution, the material was dehydrated through a series of graded ethanol solutions. Freeze-dried material was coated with gold and examined at $10 \mathrm{kV}$ using SEM (model S-2500; Hitachi). Growth was tested at $20,25,30$ and $37^{\circ} \mathrm{C}$ in $\mathrm{MB}$. The $\mathrm{pH}$ range for optimal growth was determined in $\mathrm{MB}$ adjusted to $\mathrm{pH} 3-10$. Salinity requirements were tested using modified $\mathrm{MB}(5 \mathrm{~g}$ peptone, $1 \mathrm{~g}$ yeast extract, $0.01 \mathrm{~g}$ $\mathrm{FePO}_{4}, 5 \mathrm{~g} \mathrm{MgCl} \cdot 6 \mathrm{H}_{2} \mathrm{O}, 1 \mathrm{~g} \mathrm{CaCl} 2.2 \mathrm{H}_{2} \mathrm{O}, 11$ distilled water) supplemented with $0,1,2,3,4,5,6$ or $7 \%(\mathrm{w} / \mathrm{v})$ $\mathrm{NaCl}$. Growth under anaerobic conditions was tested using $\mathrm{MB}$ after purging with nitrogen gas. Presence of oxygen was monitored using resazurin as an indicator of redox potential.

Strain US6- $1^{\mathrm{T}}$ was Gram-negative, non-motile, rod-shaped and formed yellow colonies within 2 days on MA and TSA plates at $30^{\circ} \mathrm{C}$. Cell diameter was $0 \cdot 36-0 \cdot 45 \mu \mathrm{m}$ and length $0.97-1.95 \mu \mathrm{m}$. Optimal growth occurred at $30^{\circ} \mathrm{C}$; below $20^{\circ} \mathrm{C}$, growth was retarded. The organism tolerated $\mathrm{pH}$ values from 6 to 9 (optimum 6.5). Strain US6-1 ${ }^{\mathrm{T}}$ showed essential requirements for $\mathrm{NaCl}$, as no growth was observed in medium without $\mathrm{NaCl}$. US6- $1^{\mathrm{T}}$ grew at $\mathrm{NaCl}$

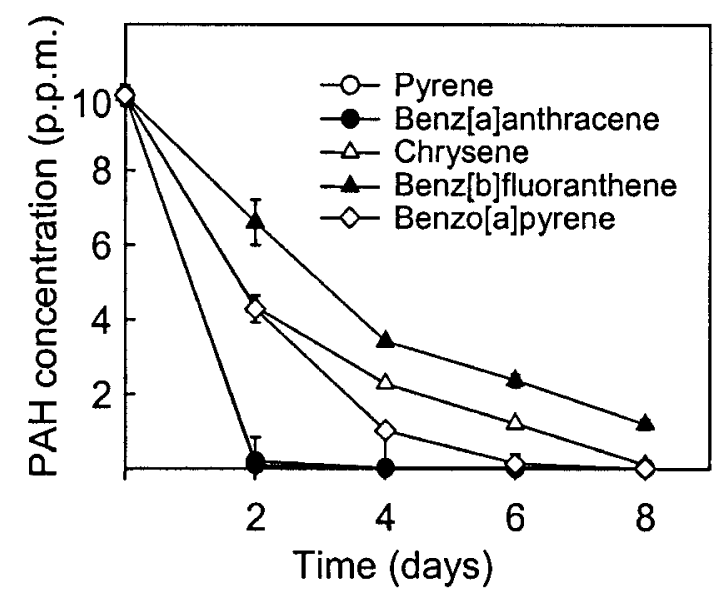

Fig. 1. Degrading activities towards five different polycyclic aromatic hydrocarbons (PAHs) by strain US6-1 ${ }^{\top}$. concentrations of 1-6\%, with optimal growth at $2 \cdot 5 \%$ $\mathrm{NaCl}$. The isolate could grow under anaerobic conditions but growth was retarded.

API 20NE (bioMérieux) and Microlog GN2 plates (Biolog) were used for physiological and biochemical characterization according to the manufacturers' instructions, except that the solution for bacterial suspension was our modified solution $\left(5 \mathrm{~g} \mathrm{MgCl}_{2} \cdot 6 \mathrm{H}_{2} \mathrm{O}, 1 \mathrm{~g} \mathrm{CaCl}_{2} \cdot 2 \mathrm{H}_{2} \mathrm{O}, 25 \mathrm{~g} \mathrm{NaCl}\right.$ in 11 distilled water) rather than saline solution. Enzyme activity for strain US6- $1^{\mathrm{T}}$ was positive for catalase, but negative for oxidase. From the tests using the API 20NE identification kit, strain US6-1 ${ }^{\mathrm{T}}$ gave positive results for aesculin hydrolysis, nitrate reduction and assimilation of glucose, maltose and phenylacetate and negative results for $\beta$-galactosidase, indole production, arginine dehydrogenase, urease, gelatin hydrolysis, acidification from glucose and assimilation of adipate, caprate, citrate, gluconate, arabinose, malate, mannose and $\mathrm{N}$-acetylglucosamine. Some phenotypic differences were observed between strain US6- $1^{\mathrm{T}}$ and other species in the genus Novosphingobium (Table 1). Based on the Microlog system, strain US6$1^{\mathrm{T}}$ could oxidize cyclodextrin, dextrin, Tween 40 , Tween 80 , $\alpha$-D-glucose, maltose, D-trehalose, sucrose, psicose, methyl

Table 1. Phenotypic characteristics that differentiate strain US6-1 ${ }^{\top}$ from other Novosphingobium species

Strains: 1, US6-1 ${ }^{\mathrm{T}}$; 2, N. subarcticum JCM $10398^{\mathrm{T}}$; 3, N. stygium ATCC $700280^{\mathrm{T}} ; 4$, N. tardaugens JCM $11434^{\mathrm{T}} ; 5$, N. hassiacum DSM $14552^{\mathrm{T}}$; 6, N. capsulatum ATCC $14666^{\mathrm{T}} ; 7$, N. rosa ATCC $51837^{\mathrm{T}} ; 8$, N. subterraneum ATCC $700279^{\mathrm{T}}$; 9, N. aromaticivorans ATCC $700278^{\mathrm{T}}$. Data in columns 2-9 were taken from Fujii et al. (2003) and Kämpfer et al. (2002). All strains show yellowcoloured colonies and are positive for catalase and nitrate reductase activity. All strains were negative for oxidase, arginine dihydrogenase and urease activities, production of indole, acid production from glucose and assimilation of $n$-capric acid and citrate.

\begin{tabular}{|c|c|c|c|c|c|c|c|c|c|}
\hline Characteristic & 1 & 2 & 3 & 4 & 5 & 6 & 7 & 8 & 9 \\
\hline \multicolumn{10}{|l|}{ Assimilation of: } \\
\hline Glucose & + & + & + & - & + & + & + & + & + \\
\hline L-Arabinose & - & + & + & - & - & + & + & + & + \\
\hline D-Mannose & - & - & + & - & - & + & + & + & + \\
\hline D-Mannitol & - & + & + & - & - & + & - & - & + \\
\hline $\mathrm{N}$-Acetylglucosamine & - & + & - & - & - & + & - & - & - \\
\hline Maltose & + & + & + & - & - & + & + & + & + \\
\hline Gluconate & - & - & - & - & - & + & + & - & - \\
\hline Adipic acid & - & - & - & - & - & - & - & - & + \\
\hline DL-Malate & - & + & - & - & - & + & - & - & - \\
\hline Phenyl acetate & + & - & - & - & - & - & - & - & - \\
\hline \multicolumn{10}{|l|}{ Enzyme activity: } \\
\hline$\beta$-Glucosidase & + & + & + & - & - & + & + & + & + \\
\hline Gelatinase & - & - & - & - & - & + & - & - & - \\
\hline$\beta$-Galactosidase & - & + & + & - & - & + & + & + & + \\
\hline
\end{tabular}


pyruvate, $\beta$-hydroxybutyric acid, $\alpha$-ketobutyric acid, propionic acid, acetic acid, quinic acid, L-alanine, L-alanyl glycine, L-aspartic acid, L-glutamic acid, L-proline, L-threonine and L-phenylalanine. These traits clearly differentiate US6-1 ${ }^{\mathrm{T}}$ from Novosphingobium subarcticum (formerly Sphingomonas subarctica; Nohynek et al., 1996).

Cellular lipids extracted from cells cultivated in $\mathrm{MB}$ at $25^{\circ} \mathrm{C}$ according to Folch et al. (1957) were transesterified into methyl esters by using strong acid methanolysis (Carreau \& Dubacq, 1978) for GC analysis. Detected peaks were identified by the fatty acid methyl-ester standard (Supelco) and equivalent chain-length values (Christie, 1988). Mass spectral verification was additionally performed using a model HP5971 mass-selective detector interfaced with a model HP5890 series II GC equipped with a HP ultra- 1 capillary column $(30 \mathrm{~m} \times 0 \cdot 25 \mathrm{~mm}$ internal diameter) and the CHEMSTATION program. Oven temperature was held at $200{ }^{\circ} \mathrm{C}$. The dominant fatty acids in strain US6- $1^{\mathrm{T}}$ were octadecanoic acid $(18: 1 \omega 7,62 \cdot 6 \%)$, hexadecanoic acid $(16: 1 \omega 7,6 \cdot 7 \%)$ and 2-hydroxy-myristic acid $(14: 02-\mathrm{OH}, 19 \cdot 7 \%)$, the last being the dominant hydroxy fatty acid. Fatty acid profiles of strain US6- $1^{\mathrm{T}}$ and other Novosphingobium species are given in Table 2. Respiratory quinones were analysed from $100 \mathrm{mg}$ lyophilized cells according to the method of Kim et al. (2000). Ubiquinone standards were purchased from Sigma (Q-9, Q-10) and also prepared from Serratia proteamaculans (Q-8). Strain US6- $1^{\mathrm{T}}$ contained ubiquinone Q-10. Sphingolipids were analysed according to the method of Christie (1988) and the presence of sphingosine was confirmed on TLC plates (Silicagel G-60; Merck).
$16 \mathrm{~S}$ rDNA was prepared and purified as described by Lee et al. (1999). Sequencing was performed using a BigDye terminator cycle sequencing kit (PE Applied Biosystems) and an Applied Biosystems model 3100 automatic DNA sequencer (PE Applied Biosystems). The resultant sequence (1481 bp) of strain US6- $1^{\mathrm{T}}$ was compared against the $16 \mathrm{~S}$ rRNA gene sequences held in the GenBank and Ribosomal Database Project (RDP; Maidak et al., 1994), and indicated that the organism was placed between the genera Novosphingobium and Sphingopyxis. The closest relatives are N. subarcticum $\mathrm{KF1}^{\mathrm{T}}(96 \cdot 23 \% 16 \mathrm{~S}$ rRNA gene sequence similarity), Sphingopyxis alaskensis $\mathrm{AF} 01^{\mathrm{T}}(96 \cdot 18 \%)$ and Sphingopyxis witflariensis $\mathrm{W}-50^{\mathrm{T}}(95 \cdot 54 \%)$. Therefore, the sequence of strain US6- $1^{\mathrm{T}}$ was aligned manually with representative sequences of the Sphingomonadaceae obtained from the RDP and GenBank databases, using known 16S rRNA secondary structure information (Gutell, 1994). Distances (options according to Jukes \& Cantor, 1969) and clustering with Fitch-Margoliash (Fitch \& Margoliash, 1967) methods were determined using bootstrap values based on 1000 replications (Felsenstein, 1985). The phylogenetic trees were rooted using Rhodospirillum rubrum and Acetobacter aceti as outgroups. The PHYLIP package (Felsenstein, 1993) was used for all analyses. Phylogenetic analysis was carried out using 1370 unambiguously aligned nucleotide positions. Strain US6$1^{\mathrm{T}}$ was placed in the genus Novosphingobium and is most closely related to N. subarcticum (Fig. 2). Sequence similarity to N. subarcticum $(96.42 \%)$ indicates that strain US6- ${ }^{\mathrm{T}}$ represents a novel Novosphingobium species. However, DNA-DNA relatedness between US6- $1^{\mathrm{T}}$ and $N$. subarcticum $\mathrm{KF}-1^{\mathrm{T}}$ using the dot-blot direct binding assay

Table 2. Cellular fatty acid compositions (\%) of strain US6-1 ${ }^{\top}$ and other Novosphingobium species

Strains: 1, US6- $1^{\mathrm{T}} ; 2$, N. subarcticum JCM $10398^{\mathrm{T}} ; 3$, N. stygium ATCC $700280^{\mathrm{T}} ; 4$, N. tardaugens JCM $11434^{\mathrm{T}} ; 5$, N. hassiacum DSM $14552^{\mathrm{T}} ; 6$, N. capsulatum ATCC $14666^{\mathrm{T}} ; 7$, N. rosa ATCC $51837^{\mathrm{T}} ; 8$, N. subterraneum ATCC $700279^{\mathrm{T}} ; 9$, N. aromaticivorans ATCC $700278^{\mathrm{T}}$. Data were taken from Fujii et al. (2003) and Kämpfer et al. (1997, 2002). Values are percentages of total fatty acids.

\begin{tabular}{|c|c|c|c|c|c|c|c|c|c|}
\hline Fatty acid & 1 & 2 & 3 & 4 & 5 & 6 & 7 & 8 & 9 \\
\hline \multicolumn{10}{|c|}{ Saturated fatty acids } \\
\hline $12: 02-\mathrm{OH}$ & $0 \cdot 8$ & - & - & - & - & - & - & - & $1 \cdot 0$ \\
\hline $13: 02-\mathrm{OH}$ & - & - & - & - & - & - & - & - & $2 \cdot 6$ \\
\hline $14: 0$ & $0 \cdot 6$ & - & - & $0 \cdot 2$ & - & $0 \cdot 6$ & $1 \cdot 5$ & $0 \cdot 9$ & 0.5 \\
\hline $14: 02-\mathrm{OH}$ & $19 \cdot 7$ & $7 \cdot 6$ & $14 \cdot 9$ & $12 \cdot 0$ & $17 \cdot 2$ & 1.9 & $12 \cdot 8$ & $13 \cdot 0$ & $16 \cdot 8$ \\
\hline $15: 0$ & - & - & - & - & - & - & - & - & $0 \cdot 9$ \\
\hline $15: 02-\mathrm{OH}$ & $0 \cdot 3$ & - & $2 \cdot 5$ & - & $19 \cdot 2$ & - & - & $3 \cdot 3$ & $4 \cdot 5$ \\
\hline $16: 0$ & $1 \cdot 0$ & $10 \cdot 2$ & $2 \cdot 5$ & $3 \cdot 1$ & - & $21 \cdot 0$ & $10 \cdot 9$ & $4 \cdot 7$ & $2 \cdot 4$ \\
\hline $16: 02-\mathrm{OH}$ & $2 \cdot 5$ & $2 \cdot 1$ & - & - & - & - & - & - & - \\
\hline $18: 0$ & - & - & - & - & - & - & - & $3 \cdot 2$ & - \\
\hline \multicolumn{10}{|c|}{ Unsaturated fatty acids ${ }^{\star}$} \\
\hline $16: 1^{a}$ & $8 \cdot 8$ & $15 \cdot 5$ & 0.6 & $15 \cdot 6$ & $16 \cdot 7$ & $5 \cdot 1$ & $22 \cdot 8$ & $20 \cdot 1$ & $20 \cdot 7$ \\
\hline $17: 1^{b}$ & $2 \cdot 0$ & $3 \cdot 3$ & $4 \cdot 9$ & $2 \cdot 6$ & $19 \cdot 3$ & 0.5 & - & $7 \cdot 4$ & $12 \cdot 8$ \\
\hline $18: 1^{c}$ & $64 \cdot 0$ & $61 \cdot 1$ & $57 \cdot 3$ & $55 \cdot 0$ & $23 \cdot 6$ & $66 \cdot 0$ & $52 \cdot 0$ & $48 \cdot 2$ & $37 \cdot 7$ \\
\hline
\end{tabular}

${ }^{\star}$ Contained one or more of the following fatty acids: $a, 16: 1 \omega 5 c$ and/or $16: 1 \omega 7 c ; b, 17: 1 \omega 6 c$ and/or $17: 1 \omega 8 c ; c, 18: 1 \omega 7 c, 18: 1 \omega 5 c, 18: 1 \omega 9 t$ and/or $18: 1 \omega 12 t$. cis and trans isomers are indicated by the suffixes $c$ and $t$. 


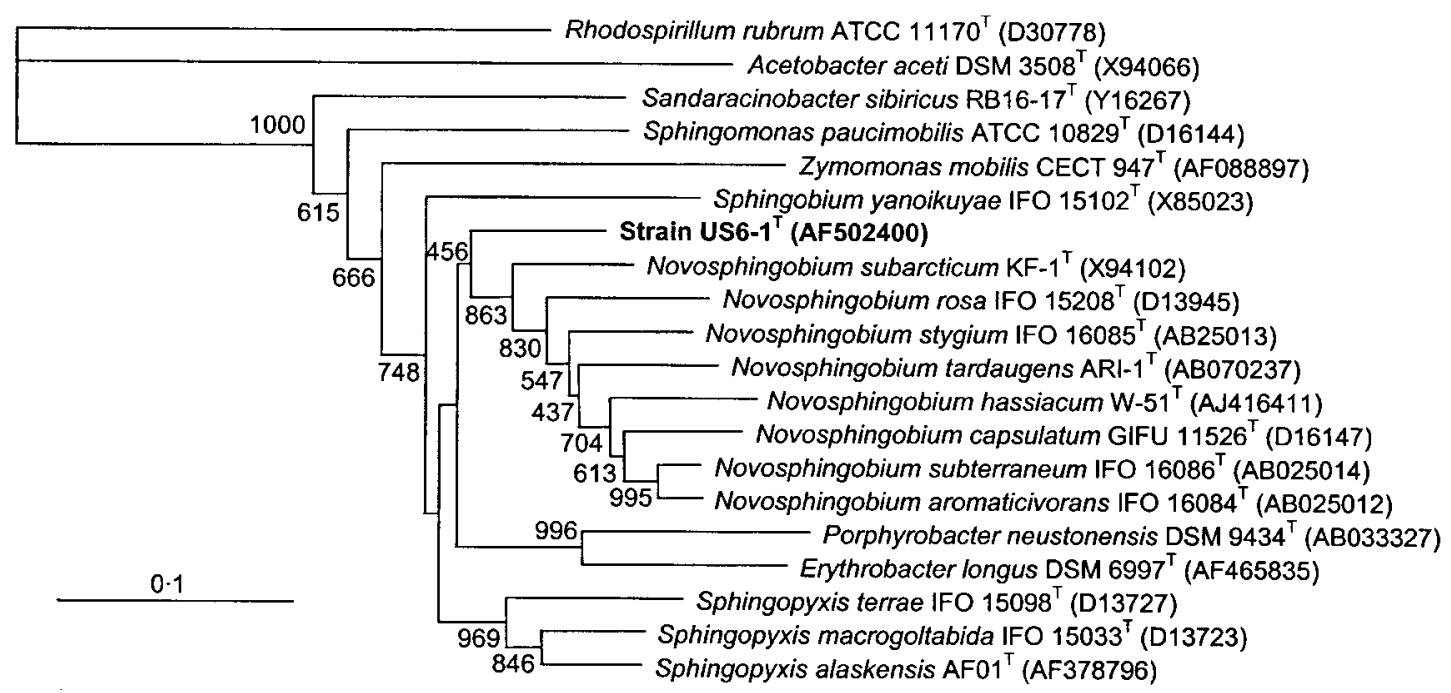

Fig. 2. Rooted Fitch-Margoliash tree based on nearly complete $16 \mathrm{~S}$ rRNA gene sequences (1370 aligned positions) showing relationships between strain US6-1 ${ }^{\top}$, Novosphingobium species and some other members of the Sphingomonadaceae. The numbers at the nodes indicate the levels of bootstrap support based on Fitch-Margoliash analyses of 1000 resampled datasets. Bar, $0 \cdot 1$ nucleotide substitutions per nucleotide position.

described by Kim et al. (2000) was only $20 \cdot 4 \%$. The G + C content of the genomic DNA was determined using the thermal denaturation method of Kim et al. (2000). The DNA G + C content of US6 $-1^{\mathrm{T}}$ was $61 \cdot 1 \mathrm{~mol} \%$.

On the basis of morphological, physiological and chemotaxonomic properties, together with DNA-DNA hybridization and $16 \mathrm{~S}$ rDNA sequence comparison data, strain US6- $1^{\mathrm{T}}$ is proposed as a novel species of the genus Novosphingobium, Novosphingobium pentaromativorans sp. nov.

\section{Description of Novosphingobium pentaromativorans sp. nov.}

Novosphingobium pentaromativorans (pen'ta.ro.ma'ti.vo.rans. Gr. numeral penta five; L. gen. n. aromatis of spice; L. v. voro devour; N.L. neut. adj. pentaromativorans degrading/ devouring aromatic compounds with five rings).

Cells are Gram-negative, non-motile rods, 0.36-0 $45 \times 0 \cdot 97-$ $1.95 \mu \mathrm{m}$. Colonies on solid MA and TSA are yellowish. Catalase-positive, oxidase-negative and facultative anaerobic growth. Positive results for aesculin hydrolysis, nitrate reduction, assimilation of glucose, maltose and phenyl acetate are obtained from API 20NE kit. Oxidizes cyclodextrin, dextrin, Tween 40, Tween $80, \alpha$-D-glucose, maltose, D-trehalose, sucrose, psicose, methyl pyruvate, $\beta$-hydroxybutyric acid, $\alpha$-ketobutyric acid, propionic acid, acetic acid, quinic acid, L-alanine, L-alanyl glycine, L-aspartic acid, L-glutamic acid, L-proline, L-threonine and L-phenylalanine in the Microlog GN2 plate. Optimal growth at $30^{\circ} \mathrm{C}$, pH 6.5 and $2.5 \% \mathrm{NaCl}$. The strain obligately requires $\mathrm{NaCl}$ for growth. Degrades fluorene, phenanthrene, fluoranthene, anthracene, pyrene, benz[a]anthracene, chrysene, benz[b]fluoranthene and benzo[a]pyrene. The major respiratory quinone is ubiquinone 10 . Genomic DNA G + C content is $61 \cdot 1 \mathrm{~mol} \%$. Dominant fatty acids are octadecanoic acid $(18: 1 \omega 7)$, hexadecanoic acid $(16: 1 \omega 7)$ and 2-hydroxy-myristic acid (14:0 2-OH); sphingosine is present.

The type strain is US6- $1^{\mathrm{T}}\left(=\right.$ KCTC $\left.10454^{\mathrm{T}}=\mathrm{JCM} 12182^{\mathrm{T}}\right)$.

\section{Acknowledgements}

We thank Professor H. G. Trüper for nomenclature relating to the novel species. This work was supported by the Ecotechnopia Program, Ministry of Environment, and the 21C Frontier Microbial Genomics and Applications Center Program and Ministry of Science \& Technology, Republic of Korea (grant MG02-0101-001-1-0-0).

\section{References}

Carreau, J. P. \& Dubacq, J. P. (1978). Adaptation of the macro-scale method to the micro-scale for fatty acid methyl transesterification of biological lipid extracts. J Chromatogr 151, 384-390.

Christie, W. W. (1988). Equivalent chain-length of methylester derivatives of fatty acids on gas chromatography. J Chromatogr 447, 305-314.

Felsenstein, J. (1985). Confidence limits on phylogenies: an approach using the bootstrap. Evolution 39, 783-791.

Felsenstein, J. (1993). PHYLIP (phylogeny inference package), version 3.5c. Distributed by the author. Department of Genetics, University of Washington, Seattle, USA.

Fitch, W. M. \& Margoliash, E. (1967). Construction of a phylogenetic tree. Science 155, 279-284.

Folch, J., Lees, M. \& Sloane Stanley, G. H. (1957). A simple method for the isolation and purification of total lipids from animal tissues. J Biol Chem 226, 497-509. 
Fujii, K., Satomi, M., Morita, N., Motomura, T., Tanaka, T. \& Kikushi, S. (2003). Novosphingobium tardaugens sp. nov., an oestradiol-degrading bacterium isolated from activated sludge of a sewage treatment plant in Tokyo. Int J Syst Bacteriol 53, 47-52.

Gutell, R. R. (1994). Collection of small subunit (16S- and 16S-like) ribosomal RNA structures: 1994. Nucleic Acids Res 22, 3502-3507.

Juhasz, A. L. \& Naidu, R. (2000). Bioremediation of high molecular weight polycyclic aromatic hydrocarbons: a review of the microbial degradation of benzo[a]pyrene. Int Biodeterior Biodegrad 45, 57-58.

Jukes, T. H. \& Cantor, C. R. (1969). Evolution of protein molecules. In Mammalian Protein Metabolism, vol. 3, pp. 21-132. Edited by H. N. Munro. New York: Academic Press.

Kämpfer, P., Denner, E. B. M., Meyer, S., Moore, E. R. B. \& Busse, H.-J. (1997). Classification of "Pseudomonas azotocolligans" Anderson 1955, 132, in the genus Sphingomonas as Sphingomonas trueperi sp. nov. Int J Syst Bacteriol 47, 577-583.

Kämpfer, P., Witzenberger, R., Denner, E. B. M., Busse, H. J. \& Neef, A. (2002). Novosphingobium hassiacum sp. nov., a new species isolated from an aerated sewage pond. Syst Appl Microbiol 25, 37-45.

Kim, S.-J., Chun, J., Bae, K. S. \& Kim, Y.-C. (2000). Polyphasic assignment of an aromatic degrading Pseudomonas sp., strain DJ77, in the genus Sphingomonas as Sphingomonas chungbukensis sp. nov. Int J Syst Bacteriol 50, 1641-1647.
Kiyohara, H., Nagao, K. \& Yana, K. (1982). Rapid screen for bacteria degrading water-insoluble, solid hydrocarbons on agar plates. Appl Environ Microbiol 43, 454-457.

Lee, J.-H., Shin, H.-H., Lee, D.-S., Kwon, K. K., Kim, S.-J. \& Lee, H. K. (1999). Bacterial diversity of culturable isolates from seawater and a marine coral, Plexauridae sp., near Mun-Sum, Cheju-Island. J Microbiol 37, 193-199.

Maidak, B. L., Larsen, N., McCaughey, M. J., Overbeek, R., Olsen, G. J., Fogel, K., Blandy, J. \& Woese, C. R. (1994). The Ribosomal Database Project. Nucleic Acids Res 22, 3485-3487.

Nohynek, L. J., Nurmiaho-Lassila, E. L., Suhonen, E. L., Busse, H. J., Mohammadi, M., Hantula, J., Rainey, F. \& Salkinoja-Salonen, M. S. (1996). Description of chlorophenol-degrading Pseudomonas sp. strains $\mathrm{KF}^{\mathrm{T}}, \mathrm{KF} 3$ and NKF1 as a new species of the genus Sphingomonas, Sphingomonas subarctica sp. nov. Int J Syst Bacteriol 46, 1042-1055.

Sanger, D. M., Holland, A. F. \& Scott, G. I. (1999). Tidal creek and salt marsh sediments in South Carolina coastal estuaries: II. Distribution of organic compounds. Arch Environ Contam Toxicol 37, 458-471.

Shin, S.-K., Oh, Y.-S. \& Kim, S.-J. (1999). Biodegradation of phenanthrene by Sphingomonas sp. Strain KH3-2. J Microbiol 37, 185-192.

Skerman, V. B. D. (1967). A Guide to the Identification of the Genera of Bacteria. Baltimore: Williams \& Wilkins.

ZoBell, C. E. (1946). Marine Microbiology. A Monograph on Hydromicrobiology. Waltham, MA: Chronica Botanica. 